\title{
Obituary: Remembering Professor Oktay Kadayıfçı (1942-2015)
}

\author{
Mertihan Kurdoğlu ${ }^{1^{*}}$, Arash Khaki ${ }^{(\mathbb{D}}$
}

Professor Oktay Kadayıfçı was born in Amasya in 1942. He completed his primary education in Bafra (Samsun), secondary education in Kabataş High School for Boys and Robert College (Istanbul). He graduated from the Faculty of Medicine of Istanbul University in 1967 and in the same year, he passed the entrance examination for being a specialization student in Istanbul University, Faculty of Medicine, Department of Obstetrics and Gynecology. Until he began to work at this Department, he had been employed in the Department of Microbiology and Outbreaks of the same faculty in order to increase his knowledge as well as to become the responsible person in the Genital Infection Division of the Department for a period of 11 months.

In 1968, he started to study in the Department of Obstetrics and Gynecology of the same faculty and in 1972, he became an expert assistant. He worked as an assistant specialist in the same department for 2 months.

He went to military service in 1972 and completed it as an Obstetrics and Gynecology Specialist at the Military Hospital in Tatvan.

In 1974, he started to his career in Çukurova University Faculty of Medicine where he worked until 1976. In 1976, he was sent to University of London, Charing Cross Medical School by the Faculty of Medicine of Çukurova University. During this period, he worked with Prof. Bagshawe from Oncology Department of the same university for 3 months. He also worked in the Endocrinology Laboratory of the same university for an additional 3 months. At the same time, he also served as a director of a project named as "A new placenta perfusion system and the investigation of the substance exchange methods of the placenta which survives in vitro with this system" in the Research Laboratory of the same University.

In 1978, he returned to Çukurova University Faculty of Medicine. In 1979, he completed his associate professorship thesis with the title of "A new placenta perfusion system and the investigation of the substance exchange methods of the placenta which survives in vitro with this system" and he received the title of "University

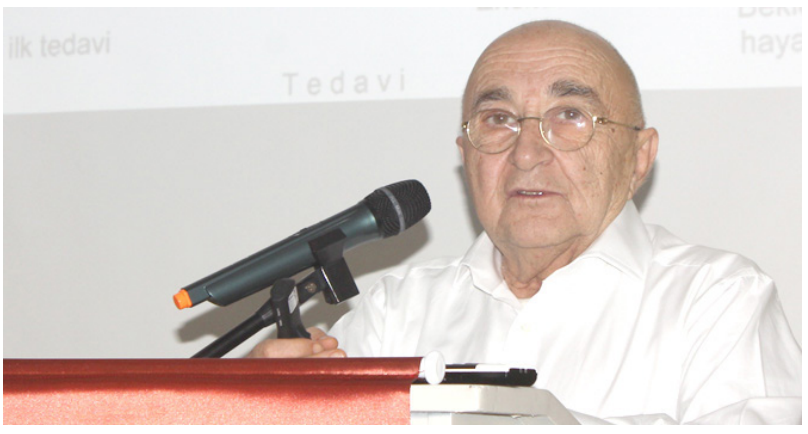

Associate Professor" on January 29, 1980. Since then, he worked as a faculty member at the same university.

He served as President of the Adana Medical Chamber. Between 1980-1995, he was the founder and consultant in the Obstetrics and Gynecology Department of the U.S.A.F. Det. 47 Hospital (Adana-İncirlik). He became Professor on January 27, 1989. Between 1998 and 2009, he worked as the head of Obstetrics and Gynecology Department at Çukurova University Faculty of Medicine. In 1991, he founded the Perinatal Diagnosis Center (PERITAM).

He organized "Women's Health" and "Menopause" meetings by bringing "Geriatric Gynecology" concept to Turkey. In Turkey, he leaded to the establishment of "Adolescent Gynecology". Her work on birth with the "Lamaze Method" spread throughout Turkey.

He made important contributions to the development of Turkish \& Greek friendship. He was an honorary member of Turkey Business Women's Association "TIKKAD". Together with TİKAD, he was awarded with "Grand National Assembly of Turkey Outstanding Service Award" in 2007. He was president of the New European Surgical Academy (NESA) in Turkey. This cooperation brought new surgical techniques to Turkey. Prof. Dr. Oktay Kadayıfçı's contribution was enormous in making Çukurova University among the top 500 universities in the world. He also worked on Robotic Surgery.

While he was working in Çukurova University Faculty of Medicine, he was one of the founders, originators and

Received 2 December 2018, Accepted 20 December 2018, Available online 10 January 2019

${ }^{1}$ Department of Obstetrics and Gynecology, Kırıkkale University Faculty of Medicine, Kırıkkale, Turkey. ${ }^{2}$ Women Reproductive Health Research Center, Tabriz University of Medical Sciences, Tabriz, Iran.

*Corresponding Author: Mertihan Kurdoğlu, MD, Email: mkurdoglu@yahoo.com 
the most actively working person of the "International Medical School" which would be established with a new vision in Europe. He retired from the Faculty of Medicine of Çukurova University in 2009. He continued to work actively in Onkim Stem Cell Technologies until his death on November 28, 2015. Apart from many scientific publications, his book "The Gentleman Like Atatürk and Being Stylish" received great attention. He was also Editor in Chief of our journal International Journal of Women's Health and Reproduction Sciences.

He always said to his students: "If you do not pass me, I will not give you my right." and "You have to pass your teacher to be a teacher, and you must train a student to pass you."
We thank our teachers' teacher, Professor Oktay Kadayıfçı for his enormous contributions to Adana, Turkey and the World.

Dear Prof. Dr. Oktay Kadayıfçı, as the students you have raised, your collegues and the editors of this journal, we promise to follow your vision and carry it to the next generations.

Rest in Peace...

\section{Conflict of Interests}

Authors declare that they have no conflict of interests.

\section{Ethical Issues}

Not applicable.

(c) 2019 The Author (s); This is an open-access article distributed under the terms of the Creative Commons Attribution License (http://creativecommons.org/licenses/by/4.0), which permits unrestricted use, distribution, and reproduction in any medium, provided the original work is properly cited. 